\title{
Georgica and Orphica: The Georgics in the Context of Orphic Poetry and Religion
}

My aim in this chapter is to open new perspectives on the Georgics by contextualizing the poem alongside surviving fragments of Orphic poetry: my central claim is that the figure of Orpheus in the fourth Georgic evokes the kind of literature that was attributed to Orpheus' authorship in antiquity, of which many fragments survive. The perspectives are newly available because our knowledge of Orphic poetry has been substantially increased in recent decades by the discovery and publication of new evidence, ${ }^{1}$ and because the Orphic fragments are now readily accessible in the recently completed, monumental collection of Alberto Bernabé. ${ }^{2}$ Moreover, there has been a recent surge of scholarly interest in the subject of Bacchus in Augustan poetry and culture, and critics have begun to feel his presence in the Georgics more pervasively than before. ${ }^{3}$ Orpheus is closely associated with Bacchus/Dionysus from at least the mid-fifth century BC onwards, and 'Orphic' and Bacchic mystery cults are not easily distinguishable. ${ }^{4}$ The investigation of possible evocations of Orphic texts in the poem may therefore be seen as a development of this recent perspective on the poem.

I should make clear from the start that when I refer to 'Orphic fragments' I mean specifically the fragments of theogonical poetry attributed to Orpheus (not dissimilar from Hesiod's Theogony but with certain distinctive characteristics) and the so-called 'Orphic' gold tablets. ${ }^{5}$ I will argue that an aspect of the evocation of these Orphic poems, is that both they and the Georgics conform to a more widely attested tendency within the didactic genre, whereby the text explains the current mortal condition as resulting from an original sin, and as a result, if one understands the text and its aetiological narrative correctly, one can expiate that sin and surpass one's mortal limitations. In the Georgics, the Aristaeus episode conforms to this pattern: Aristaeus learns that his bees have died out as a punishment for an earlier sin. He must then expiate this sin in order to overcome the death of his bees and bring the swarm to life again through the practice of Bugonia. This pattern - of a text which explains a sin, as a result of which one must demonstrate certain behaviours to conquer death - is paralleled in the Orphic texts and the way they seem to have been used in Orphic mystery cults, and can also be detected in Empedocles and Hesiod. First of all, I shall set out some circumstantial

\footnotetext{
${ }^{1}$ Most notably, the Derveni papyrus, which was discovered in 1962; an anonymous edition of part of the papyrus appeared on separately numbered pages at the end of ZPE 47 (1982) but the full editio princeps was only published as Kouremenos et al. (2006). There has also been a number of publications of newly discovered gold tablets, which have made clearer their association with Bacchus. Note especially the Hipponion tablet (OF474, first published in 1974), which mentions the 'sacred road which initiates and famous Bacchoi follow' (lines 15-6); and the two tablets from Pherae (OF485-6, first published in 1987) and the tablet from Amphipolis (OF196n, first published 2001) which mention Bacchus.

${ }^{2}$ Bernabé (2004-7).

${ }^{3}$ On Bacchus in the Georgics see Gowers (2016) and Mac Góráin (2014).

${ }^{4}$ See Bremmer (2014) 55-80, and note Hdt. 2.81.

${ }^{5}$ Whilst no ancient authority attributes the text of the gold tablets to Orpheus, Bernabé and San Cristóbal (2008) 179-89 present good reasons for accepting the traditional interpretation that Orpheus was believed to be their author.
} 
evidence which makes Virgil's acquaintance with Orphic texts and religion plausible, then I shall investigate some more specific parallels between the narrative of the Georgics and that of the Orphic theogonies. Finally I will briefly survey this pattern within didactic and make some comments on the effect of the evocation of this kind of literature on the Georgics as a whole.

\section{Circumstantial Evidence}

Orphic influence on Virgil has in fact long been identified in Aeneid 6. Norden argued that the katabasis of Aeneas was in part modelled on an earlier hexameter Katabasis of Orpheus (OF 707-13), of which no verbatim fragments survive. ${ }^{6}$ More recently, Nicholas Horsfall and Jan Bremmer have argued that the description of the Tartarus (548-636) in Aeneid 6, in particular that of the sinners at 548-636, is also modelled on an Orphic Katabasis. ${ }^{7}$ The evidence for this hypothesis is that Virgil's description of the sinners bears certain similarities with those described in the Bologna papyrus (OF 717= PBonon.4 c.2-4AD), a hexameter text thought to date from the early Empire, and which describes the punishment of certain sinners in the underworld. ${ }^{8}$ Horsfall and Bremmer argue that a common source, an earlier Orphic Katabasis, lies behind both texts. If we accept this argument, it is of course possible that such a poem was in some sense a model for Orpheus' descent to the underworld in Georgics 4, but it should be noted that the description at Georgics 4.474-84 does not feature the extended description of punished sinners that seems to be the key point of similarity between the Aeneid and Bologna papyrus descriptions. The evidence is even more speculative than with most Orphic material. We do, however, have more evidence for the theogonical poetry attributed to Orpheus which, I shall argue, reveals certain significant thematic similarities with the Georgics.

There is some clear evidence that an Orphic theogony was circulating in Rome in the first century, and that Virgil was familiar with it. The transmission and interrelation of the various Orphic theogonies is a complex topic which I cannot go into in detail. ${ }^{9}$ Suffice it to say that the

\footnotetext{
${ }^{6}$ Norden (1927) 5 n.2. Perhaps Norden's strongest evidence for his argument is the similarity between A. 6.120 and a line from the fifth century AD Orphic Argonautica (42), which occurs in a passage which may to refer to an earlier Katabasis of Orpheus. The earliest explicit mention of the Katabasis attributed to Orpheus is found in Clement of Alexandria (OF 707). See also Sevius ad A.6.392f.

${ }^{7}$ Horsfall (1993) and (2013) ad 548-636; Bremmer (2014) 187-193.

${ }^{8}$ See Bremmer (2014) 187-193.

9 The most clear and detailed attempt to reconstruct the interrelation of the different Orphic theogonies circulating in antiquity is still West (1983); although he is perhaps a little over-confident in his reconstructions. See the review by Graf (1985). Damascius, writing in the early 6th century CE distinguishes three different Orphic theogonies (Princ. 123-4 (i. 316-9 Ruelle)) and West distinguishes a further three (pp.68-9): the 'Cyclic theogony' which stood at the beginning of the Epic Cycle, the theogony quoted in the Derveni papyrus, and the 'Protogonos theogony' from which he argues that the Derveni theogony is an abridgement, although the existence of the latter has been disputed. For alternative reconstructions and discussion see Betegh (2004) 92-131, Burkert (2005) and Bernabé (2002). For a full bibliography on Orphic theogonies see Bernabé (2004-7) fasc. 1 XXVIII-XLII. The editio princeps of the Derveni papyrus has been published as Kouremenos et al. (2006).
} 
earliest fragments of Orphic theogony are found in the Derveni papyrus, but they are most copiously found in the Neoplatonists, who had an Orphic theogony in 24 Rhapsodes which was assembled from the various earlier Orphic theogonies and which shares some characteristic episodes with the Derveni theogony. Martin West dates the assembly of the rhapsodic theogony to around $100 \mathrm{BC}$, so under his dating it could have been available to Virgil and his readers. ${ }^{10}$ Cicero mentions an Orphic theogony, which could suggest that such a poem was available in first century Rome. ${ }^{11}$ The poem certainly seems to have been available by the time of Apuleius, and Philodemus also demonstrates awareness of this poetry, making Virgil's acquaintance with it most likely. ${ }^{12}$

In Virgil, where Orpheus' name occurs in Eclogues 4 and 6, it is associated with the composition of theogonical poetry. In Eclogue 4, the narrator is compared with Orpheus at 55-6:

non me carminibus uincet nec Thracius Orpheus

nec Linus, huic mater quamuis atque huic pater adsit

Then shall neither Thracian Orpheus nor Linus defeat me in song, though mother give aid to the one and father to the other

Servius comments ad loc.: genere stili se Orpheo vel Lino meliorem fore commemorat 'he relates that he will be better at this type of writing than Orpheus or Linus'. 'This type of writing' surely refers to theogonical poetry, as the surviving fragments of Linus, like the majority of the Orphic fragments, are theogonical in nature. ${ }^{13}$ In the Eclogue, the golden age imagery and the return of the Virgo (line 6) align the poem with Hesiod, the poet who above

\footnotetext{
${ }^{10}$ West (1983) 246-51.

${ }^{11}$ Cicero DND 1.107: Orpheum poetam docet Aristoteles numquam fuisse, et hoc Orphicum carmen Pythagorei ferunt cuiusdam fuisse Cercopis 'Aristotle teaches that the poet Orpheus never existed, and the Pythagoreans claim that this Orphic poem was by a certain Cercops'. See Dyck (2003) ad loc. for a discussion of the origin of the poem. Cf. also DND 1.40-1 which mentions Chrysippus' allegorizing interpretations of Orpheus. Further evidence of Orphic theogony in first century BC Rome is Nigidius ap. Servius In Vergilii Bucolicon Librum 4.10.1): Nigidius de diis lib. iv. "quidam deos et eorum genera temporibus et aetatibus <dispescunt>, inter quos et Orpheus primum regnum Saturni, deinde lovis, tum Neptuni, inde Plutonis" 'Nigidius in his fourth book on the gods writes, "some <separate> the gods and their families by their times and ages, among whom Orpheus also distinguishes the first reign of Saturn, then the one of Jupiter, then of Neptune, then of Pluto.")

${ }^{12}$ Apuleius quotes from an Orphic poem at de Mund. 401 a $25(=$ OF31). Whilst his quotation appears to be from a hymn to Zeus, Bernabé notes that this was probably part of a theogony. Philodemus mentions 'Orphic hymns' in On Piety PHerc. 1428 fr. 3 (for a text of which see Obbink (1994)) and alludes to episodes from Orphic theogony at On Piety 192-3 (II.4956-4969) and, apparently, On Poems 181 Janko (on which see the editor's comment). One of the gold tablets (OF491), dated to the second century CE, was discovered at Rome.

${ }^{13}$ For the surviving fragments of Linus see Bernabé (2004-7) Fasc. 3 54-104 or, with discussion, West (1983) 56-67.
} 
all sang of the origins of man and the gods. ${ }^{14}$ In Eclogue 6, the song of Silenus is a cosmogony which is usually understood to be modelled on the cosmogonical song of Orpheus in Apollonius' Argonautica (1.496-511). ${ }^{15}$ But there are good reasons for thinking that Virgil was aware of Orphic theogony beyond Apollonius' depiction: firstly, there is the circumstantial Roman period evidence mentioned above; secondly, there are the possible connections between Aeneid 6 and an Orphic Katabasis mentioned above; and thirdly, in Eclogue 4, there is the pattern of an ancient guilt (13 si qua manent sceleris vestigia nostra) which is to be atoned for, to realise a pre-fall state, expressed (as in Hesiod, the Orphic theogony and Empedocles) in terms of the golden age, a pattern which we also find in the Orphic theogonies, but not in Apollonius. Moreover, in Eclogue 6 the stock episode of getting a god drunk and binding him so that he tells you something is paralleled in an episode of the Orphic succession myth in which Zeus gets Cronos drunk with honey, then binds him and castrates him, after which Cronos graciously tells him how he is subsequently to gain control of the universe. ${ }^{16}$ These binding episodes also bear comparison with the binding of Proteus by Menelaus in Odyssey 4 and by Aristaeus in Georgics 4: in the Georgics passage too, the binding may evoke Orphic theogony as well as the Odyssey and Eclogue passages. So whilst Orpheus' theogony in the Argonautica is significant, it also makes sense to think of the theogonical poems attributed independently to Orpheus in antiquity when his name occurs in Virgil.

When we come to the Georgics, the emphasis on the southern Italian context in the sphragis of the poem (4.563-4), which indicates that the poem was written at Naples, may serve to hint at an association with Orphism and mystery cult. Magna Graecia was a hotbed for Orphic religion and mystery cult more generally: the area has yielded more gold tablets than any other region, and a fifth century BC burial ground at Cumae seems to have been reserved for those initiated into a Bacchic mystery cult. ${ }^{17}$ Of the didactic poets, Parmenides and Empedocles came from Magna Graecia, both of whom have been associated with Orphic or Pythagorean mystery cults. ${ }^{18}$ Parmenides' proem has also been seen as a Katabasis. ${ }^{19}$ In Aeneid 6 - a book which, as we have seen, has been seen to evoke Orphism - Aeneas enters the underworld at Cumae, in close proximity to Naples. The archaeological evidence of the

\footnotetext{
${ }^{14}$ Cf. Hesiod Op. 109-126 (the golden race) and 217-224 (Justice personified as the maiden $\Delta$ íkn). Although these parallels are with the Works and Days rather than the Theogony, the Works and Days is generically similar to theogonical works (such as those attributed to Linus and Orpheus) as it explains the origins of man, recounting two myths on the subject, that of Prometheus and Pandora (42-105) and the myth of the races (106-201).

${ }^{15}$ As noted, for instance, by Clausen (1994) 176-7. Orpheus' song in Apollonius' Argonautica is based on Empedocles' cosmology (as discussed by Hardie (1986) 62, Nelis (1992) 157-60, Hunter (1993) $162-$ 7,177 ) and has been seen as an indicator (among other evidence) that Empedocles' poem itself can be seen as an Orphic text, on which see Riedweg (1995) and Rodríguez (2005).

${ }^{16}$ OF219-225, on which see West (1983) 72.

17 On the prominence of Orphism in southern Italy, see Parker (1995) and, for the grave, Cumae, Bremmer (2014) 72. The grave bears the inscription 'It is illicit to lie buried in this place unless one has become a bakchos' (bebakcheumenon).

${ }^{18}$ See further Kingsley (1999) on Parmenides, and Riedweg (1995) on Empedocles for these associations.

${ }^{19}$ For Parmenides' journey as a Katabasis see Burkert (1969) and Kingsley (1999).
} 
gold tablets and the grave at Cumae, along with the literary evidence of Parmenides, Empedocles and Aeneid 6, may strengthen this interpretation.

This brings me onto mystery cult. It has long been believed that mystery cults are important for Aeneid 6 and I take it as sufficiently demonstrated by Llewelyn Morgan, Alexander Hardie and others that they are a prominent theme in the Georgics. ${ }^{20}$ The most clear example is the mention of Eleusis at 1.160-8:

Dicendum et quae sint duris agrestibus arma,

quis sine nec potuere seri nec surgere messes:

uomis et inflexi primum graue robur aratri,

tardaque Eleusinae matris uoluentia plaustra,

tribulaque traheaeque et iniquo pondere rastri;

uirgea praeterea Celei uilisque supellex, 165

arbuteae crates et mystica uannus lacchi;

omnia quae multo ante memor prouisa repones,

si te digna manet diuini gloria ruris.

I must tell, too, of the hardy farmers' weapons,

without which the crops could be neither sown nor raised.

First the share and the curved plough's heavy frame,

the slow-rolling wains of the Mother of Eleusis,

sledges and drags, and hoes of cruel weight;

further, the common wicker ware of Celeus,

arbute hurdles and the mystic winnowing-basket of lacchus.

All of these you will remember to provide and store away long beforehand,

if the glory the divine country is to be yours in worthy measure.

The reference to Demeter as the 'Mother of Eleusis' (Eleusinae matris) clearly alludes to the Eleusinian mysteries. The 'winnowing-basket' (vannus) is 'mystic' (mystica) and belongs to

\footnotetext{
${ }^{20}$ Morgan (1999) and Hardie (2002). See also Johnston (1977) and especially (2009). On Virgil and mystery religion more generally see Luck (1973).
} 
lacchus (lacchi) as the tool was carried by $\lambda$ ıkvoфópol in the Eleusinian procession, and lacchus, although at times identified with Bacchus, was originally a personification of the cultic cry of the participants in the Eleusinian mysteries. ${ }^{21}$ The reference to Eleusis here may be related to the anticipation of the apotheosis of Octavian mentioned earlier (1.20-42), given the initiation of Octavian into the Eleusinian mysteries in 31BC (Cass. Dio 51.4.1) two years before the publication of the poem, and the eschatological benefits conferred upon initiates. ${ }^{22}$

Bacchism comes into book 4 where Orpheus' death is likened to a Bacchic sparagmos, where a sacrificial victim is torn to pieces $(4.519-22) .{ }^{23}$ By the Hellenistic period, Orpheus is mentioned as the founder of mystery cults in general, including those at Eleusis (Diodorus 1.96.4-6), and moreover, Orphism is always closely associated with - and arguably indistinguishable from - Bacchism/Dionysism. ${ }^{24}$ Orpheus is said to have introduced the mystery cults from Egypt (Diod. Sic. 1.96.4-6 =OF 48T II), which is where the Bugonia episode is set. So the prominence of mystery cults in the poem further suggests that we are to regard Virgil's Orpheus as the founder of religious institutions; this may identify him as the Orpheus to whom the theogonies were attributed. ${ }^{25}$

\section{Specific Parallels}

I turn now to some more specific episodes in the Georgics which are paralleled in the Orphic theogonies and which associate the poem generically with that kind of literature. I have already mentioned the similarities between the binding of Proteus and the binding of Cronos: both Orpheus' Zeus and Virgil's Aristaeus go to a cave and ask a goddess for help who tells them to bind a god. ${ }^{26}$ Another parallel comes earlier in book 4 in the mention of Juppiter's childhood in the Dictaean cave, where he is fed honey and guarded by the noisy Curetes (4.149-52 cf.2.536):

Nunc age, naturas apibus quas luppiter ipse

addidit expediam, pro qua mercede canoros

\footnotetext{
${ }^{21}$ For the $\lambda$ ıкvoфópo see Mynors (1990) ad loc. who cites Callim.Cer.126. For lacchus see Graf (2006).

${ }^{22}$ See Hardie (2002) 178.

${ }^{23}$ See Morgan (1999) 153-4.

${ }^{24}$ For Orpheus and Eleusis see Graf (1974); for the connections and distinctions between Orphism and Bacchism see Burkert (1982), Parker (1995) and Betegh (2014). Cf. Hdt. 2.81 for the early association between Orphism and Bacchism/Dionysism (and Pythagoreanism).

${ }^{25}$ As Morgan (1999) 195 writes, both Orpheus' katabasis and his death by sparagmos 'strongly suggest that the aspect of Orpheus in play in Virgil's passage is that which placed him in proximity to mystery religion, the mysteries of Dionysus in particular but also those of Demeter and Persephone-Proserpina at Eleusis.'

${ }^{26}$ For Night in the cave in Orphic theogony see OF 6 (from the Derveni theogony). For the significance of caves as a typical location for divine revelation in Greek thought see Burkert (1969) and Ustinova (2009).
} 
Curetum sonitus crepitantiaque aera secutae

Dictaeo caeli regem pauere sub antro.

Come now, the qualities which Jove himself has given bees,

I will unfold - even the reward for which they followed

the tuneful sounds and clashing bronzes of the Curetes,

and fed the king of heaven within the cave of Dicte.

Now, the tradition that Zeus was nursed in the Dictaean cave and guarded by the Curetes is well attested in Hellenistic sources. It crops up in Aratus (at line 35) and features prominently in Callimachus' Hymn to Zeus (lines 46 - 54) where, as in Virgil, there is an emphasis on honey, and the story seems to have featured in Nicander's Georgics (or Melissurgica - depending on whether that is a separate poem, Nicander fr.94 = Columella De Re Rustica 9.2.4.5). Significantly for my purposes, the story appears in the song of Orpheus in Apollonius' Argonautica (1.508-9), and features prominently in the Rhapsodic theogony (OF 205-215), where honey is especially important, for feeding Zeus (OF 209) and for getting Cronos drunk (OF 220, 221). West has tentatively suggested that an Orphic theogony could have been the source for the Hellenistic versions of this myth. ${ }^{27}$ More importantly, Philodemus (On Poets fr.181 Janko) appears to allude to the story in an Orphic context, if Janko is correct in saying that the 'drum of an Orpheotelest' alludes to the story of the Curetes guarding Zeus. ${ }^{28}$ So in the Georgics the fact that this myth occurs in a book where Orpheus will feature so prominently, suggests that an association with 'Orpheus', as well as the Hellenistic versions, is present here.

My next example is book 4.219ff, describing a kind of pantheism where the divine pervades everything:

His quidam signis atque haec exempla secuti

esse apibus partem diuinae mentis et haustus

220

aetherios dixere; deum namque ire per omnis

terrasque tractusque maris caelumque profundum;

hinc pecudes, armenta, uiros, genus omne ferarum,

quemque sibi tenuis nascentem arcessere uitas:

\footnotetext{
${ }^{27}$ West (1983) 127-8. The Orphic theogony he suggests was available to them is the 'Eudemian theogony'.

${ }^{28}$ Janko (2000) 401 (ad fr.181).
} 
omnia nec morti esse locum, sed viva volare

sideris in numerum atque alto succedere caelo.

Led by such tokens and such instances,

Some have thought that the bees have received a share of the divine intelligence, and a draught

of heavenly ether; for God, they saw, pervades all things,

earth and sea's expanse and heaven's depth;

from him the flocks and herds, men and beasts of every sort

draw, each at birth, the slender stream of life;

to him all beings thereafter return, and when unmade, are restored;

no place is therefore death, but still quick, they fly

unto the ranks of the stars, and mount to the heavens aloft.

Thomas comments that this view 'is in essence a combination of Stoic and Pythagorean theory, but $V$. may also have in mind the famous opening of Aratus' Phaenomena' ${ }^{29}$ Yet Pantheism may also evoke Orphism: the theory appears prominently in the Orphic theogonies, where Zeus - after following the advice of the castrated Cronos, swallows the Protogonos theos, the first born god Phanes and ends up encompassing the entire universe. This is the episode alluded to in the Orphic hymn to Zeus quoted by Apuleius, ${ }^{30}$ and is testified in Orphic theogony as early as the Derveni papyrus (see OF12-4 and 425-6). Moreover, the anonymous people who, in the Georgics hold this theory, have inferred it from the nature of bees (219-21); as I have mentioned bees seem to have been particularly prominent in the Rhapsodic Theogony for getting Kronos drunk. One might tentatively suggest that the 'divine draughts' (haustus aetherios) that belong to the bees could recall the draughts of their honey drunk by the gods in the Rhapsodic Theogony. This is not to deny the Pythagorean or Stoic associations of the passage: Pythagoreanism is, from its earliest stages, closely associated with Orphism and Orphic texts, ${ }^{31}$ and Orphic poems seem

\footnotetext{
${ }^{29}$ Thomas (1988) ad loc.

${ }^{30}$ de Mund. 401 a 25 (= OF31B).

${ }^{31}$ On the two and the distinctions between them, see Burkert (1982) and now Betegh (2014). On the early connections between Orphism and Pythagoreanism see Riedweg (2005) 51-5, who argues that the early Pythagoreans derived their doctrines from allegorical interpretations of Orphic poems. Note Hdt. 2.81 and lon of Chios B2 (=D.L. 8.8) and Cicero DND 1.107.
} 
to have been particularly susceptible to Stoic allegorical interpretations. ${ }^{32}$ The placement of this description shortly before the Orpheus episode may activate the Orphic associations of the theory in particular.

Finally, when Aristaeus arrives in the cave of the nymphs, as Phillip Hardie has argued, the nymph Clymene seems to be singing a theogony at $4.345-7::^{33}$

\author{
inter quas curam Clymene narrabat inanem \\ Volcani, Martisque dolos et dulcia furta, \\ aque Chao densos diuum numerabat amores.
}

Among these Clymene was telling of Vulcan's baffled care,

of the wiles and stolen joys of Mars,

and from Chaos on was rehearsing the countless loves of the gods.

She tells of the loves of the gods a Chao. Although the most ostensible topic of her song is the adultery of Aphrodite with Ares (as sung by Demodocus at Odyssey 8.266ff.) the phrase $a$ Chao, surely evokes theogonical poetry above all, and the densi divum amores would then refer to the sexual reproduction which in that genre leads to the creation of the recognisable world. The fact that this occurs shortly before the story of Orpheus makes a connection with Orphic theogony most likely. Creation myth is evoked more generally in the Georgics by the mention of anthropogony at 1.60-6 and the recurring theme of the golden age, which features in Hesiod, Empedocles and in the theogonies attributed to Orpheus. ${ }^{34}$ So the importance of Orpheus at the end of the poem, known in antiquity as the author of theogonies, could further associate the poem with that genre.

\title{
A Pattern within Didactic
}

I have argued that certain images in book 4 (the birth of Dictaean Zeus at 149-52; the pantheism at 219-27; the theogony at 345-50), given that Orpheus occurs prominently in the Bugonia episode, and is associated with theogony elsewhere in Virgil's œuvre, may evoke Orphic theogony. This may affect our interpretation of the generic positioning of the poem, and of the function it is presented as performing. Both the Georgics and the Orphic theogonies, I suggest, conform to a particular pattern in the function of didactic hexameter

\footnotetext{
${ }^{32}$ E.g. Cic. DND 1.40-1; Plut. De defectu orac. 415f. See further West (1983) 113 and 193-6.

${ }^{33}$ Hardie (1986) pp.83-4.

${ }^{34}$ Hesiod Op.109-26; Empedocles B128; OF216B ( = Procl. in Plat. Remp. II 74, 2).
} 
texts, according to which the poem explains aetiologically an original sin so that if the student understands the text correctly, he or she can expiate that sin and overcome the negative aspects of death. This reward takes the form of access to a privileged afterlife reserved for the initiates, or possibly of divinization. ${ }^{35} \mathrm{~A}$ further characteristic feature is that the sin is part of a general decline from a historical golden age, but the golden age can again be realised if the correct instructions are followed. Both the prospect of realising the golden age and the possibility of eschatological benefits are relevant for the Georgics.

This pattern of decline stems from the Works and Days, which explains the current mortal condition aetiologically as resulting from both the myth of the races and the story of Prometheus and Pandora. Although the golden age is set in the past, one is able to realise a quasi-divine golden age by being just and following the instructions - hence the language of the land of the just city echoes that of the golden race, suggesting that they too enjoy the supernatural benefits of the golden race. ${ }^{36} \mathrm{~A}$ historic golden age also occurs in Empedocles (B128) and in the Orphic theogony as described by Proclus (Procl. in Plat. Remp. II 74, 26= OF216, 320); in both cases, the golden age appears to be something to aspire to for the present, if we follow the instructions correctly. This synchronic use of golden age imagery is also present in the Georgics notably in the laudes Italiae (2.136-76). The inconsistencies between that episode and the rest of the poem have been problematic for some, but they are perhaps less problematic if we regard the golden-age imagery not as a literal description of the actual present, but as something to aspire to provided that we follow the correct instructions, as seems to be the case in Hesiod, Empedocles and 'Orpheus'. ${ }^{37}$

In Hesiod, there is an original sin, and there is the prospect of realizing a quasi-divine golden age, and of becoming a theios anerr, but there are not yet clear eschatological benefits to following the instructions. However, this aspect of the pattern is relatively clear in Empedocles: his narrator is an exile from the immortals because of a sin committed (B115),

\footnotetext{
${ }^{35}$ For the blessed afterlife promised for mystery initiates see Pindar fr.137 and the gold tablets which most clearly evidence a blessed afterlife for the deceased, OF488, 474, 476, 477, 485, 486, 489, 490. For reincarnation in Empedocles see B117 and B137; in Plato see especially Rep. 10.617dff. and Phd. 70c ff. On Orphic metempsychosis see now Betegh (2014), who sees the clearest evidence for Orphic metempsychosis as the tablet OF488.5, but also cites Plato Meno 81a10-d4 and Pindar fr.133. Divinization is suggested most clearly in the gold tablets OF484, 487 and 491 . Empedocles implies that humans can become gods in B112.4 and B146.

${ }^{36}$ The description of the Golden Race at Op. 109-126 is echoed in the language describing the just city

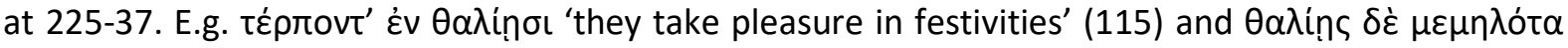

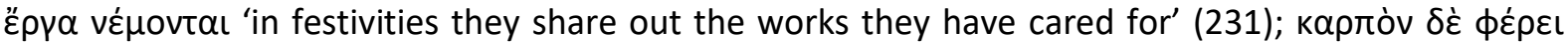
$\zeta \varepsilon i \delta \omega \rho o \varsigma$ äpoupa 'the grain-giving field bears crops' occurs at 117 and 237 . The just city enjoys a land

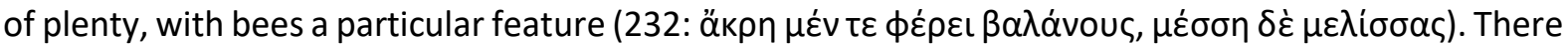

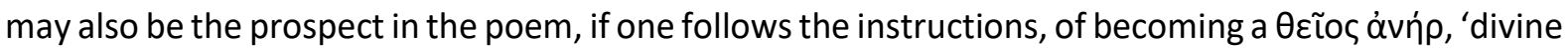
man' (731), on which see Currie (2006) and the classic treatment of Vernant (1983).

${ }^{37}$ The inconsistencies between the Laudes Italiae and depiction of Italy in the rest of the poem, see Thomas (1988) 179-80, who writes ' $V$. presents obvious fictions, demonstrably in conflict with the reality of Italy as it exists in the 'technical' sectios of the poem' (p.180). For a connections (via Aratus) between the golden age imagery in the Georgics and that in Empedocles see Nelis (2004).
} 
but if the correct instructions are followed, immortal powers and superior reincarnation await (B111). In the case of Orphism, the external evidence from Plato (and others) suggests that Orpheotelestai used books according to which they conducted rituals and were able to persuade individuals and entire cities that they could expiate their sins and so earn a blessed afterlife. ${ }^{38}$ It is likely that these kinds of texts were the sorts of theogony attested in the Derveni papyrus, as the commentator offers instructions for certain rituals (Col.II). The suggestion is that the correct understanding of the theogony enables you to perform the correct rituals to earn a blessed afterlife. The Philodemus testimonium (On Poems 181 Janko) suggests that this stereotype was still familiar in the first century BC.

An explanation of how an Orphic theogony was used aetiologically to justify certain rituals is found in the myth closely associated with Orphism, of Dionysus Zagreus, which was part of the theogony at least as early as Euphorion as his testimony demonstrates. ${ }^{39}$ In the myth, Dionysus is the son of Zeus and Persephone. As a boy, the titans murder him by slashing him into seven pieces, which they then cook and eat. In punishment for this Zeus destroys them with the thunderbolt, and from the resulting ashes humans are created. According to Olympiodorus, as a result, humans have both a divine element (from the swallowed chunks of Dionysus) and a Titanic one, and the point of ritual activities and certain practices - such as vegetarianism - are explained as an attempt to cultivate the divine and reject the Titanic. ${ }^{40}$ In Orphism, then, the text is used to explain an original sin, which must be expiated, just as Aristaeus must expiate his sin against Orpheus and Euridice. The myth of Dionysus is reflected in two of the gold tablets where the initiate is described as having been stuck down by lightening, as well as being the 'child of Heaven and Earth', a formula which may allude to human's Titanic origins. ${ }^{41}$ The gold tablets offer instructions, in hexameters (or attempted hexameters) which are to be followed in order to reach the path of the blessed and in some cases describe the initiate's divinization. ${ }^{42}$

The kinds of Orphic texts mentioned by Plato (which possibly include the Derveni theogony), the poetry of Empedocles, and the Orphic gold tablets (which seem to draw upon theogonical myth) are all supposed to enable their addressees to conquer death, either by promising them a happy and exclusive afterlife, or by granting them immortality. The Georgics, too, seems to

\footnotetext{
${ }^{38}$ Plato Resp. 364b2-365a3. See also Eur. Hipp.952-4. A papyrus decree from one of the Ptolemies (BGU 1211), ordering those who perform initiations for Dionysus in Egypt to present their 'sacred accounts' (izpoi $\lambda$ óyol), may also refer to this type of text, on which see Parker (2011) 16-7. For the possibility that the Derveni theogony was used as a 'sacred account' in this sense, as part of initiation rituals, see Obbink (1997).

${ }^{39}$ Euphorion in his Mopsopia gave an account of the Dionysus Zagreus myth, according to Philodemus On Piety 192-3 (II. 4956-4969) = OF59, who also connects the story with the Orphics. The fragment is printed in Lightfoot (2009) pp.270-1.

${ }^{40}$ In Phd. 1.3=OF 304 I; 313 II; 318 III; 320 I. Whilst Olympiodorus' interpretation may be Christianising, the myth itself clearly occurred in the tradition by the time Virgil was writing.

${ }^{41}$ Graf and Johnston (2007), and Bernabé and San Cristóbal (2008) see a connection with the myth, Edmonds (1999) and now (2013) denies a connection. See also now Betegh (2014).

${ }^{42}$ See n.35 above.
} 
conform to this pattern in its explanation of how to resurrect the bees, and in the prospective divinisation of the new Caesar, ${ }^{43}$ who himself seems to be a resurrection of the previous, dead Caesar (exstincto... Caesare, 1.466). Aristaeus' sin of raping Euridice must be atoned for to achieve the resurrection of the bees (4.453-6). If I am correct, by evoking Orphism and Orphic texts, Virgil, at least in book 4, seems to align the poem with this kind of mystic literature.

\section{Orphism and the Interpretation of the Georgics}

There are, I suggest, some respects in which this typological alignment might affect an interpretation of the poem. I have mentioned that Orphic texts seem especially to have invited allegorical interpretations. Their evocation in book 4 of the Georgics may be an additional signal that we are to apply an allegorical interpretation to the Aristaeus narrative: ${ }^{44}$ Aristaeus, as the guardian of the bees/ quirites (4.201) is Octavian, whilst Orpheus, as the urpoet, is Virgil.

A further consequence of this alignment is that it implies that the Georgics have a similar function to texts of 'Orpheus' and Empedocles, in enabling their addressee to conquer death. Formally didactic texts ${ }^{45}$ may inherently draw attention to their pragmatic force: they are presented as teaching a specific body of knowledge, and thereby modifying the attitudes and behaviour of their addressee, in a more specific manner than, say, narrative epic. The texts of the gold tablets in particular seem to have been thought to have a specific pragmatic, function, given that they were inscribed on gold and buried with the deceased. They thus seem to be instrumental in enabling their addressees to enjoy a blessed afterlife, and, in some cases, in effecting a transition from mortal to immortal. The pragmatic function of poetry is a theme which occurs prominently in the Orpheus narrative: Orpheus is initially the poet whose song, above all others, moves its hearers (4.464-484); but, once he fails to follow the instructions, his song no longer moves the spirits and divine laws of the underworld (4.505 quo fletu Manis, quae numina voce moveret?). His song ceases to have its pragmatic impact, but it does resonate even after its author has been dismembered (523-7).

This may invite us to reflect on the pragmatic force of the poem itself, especially if the Orphic parallels do indeed support the allegorical interpretation. The Georgics has a number of

\footnotetext{
${ }^{43}$ Hardie (2002) 178 argues that the divinization of Arugustus at 1.24-42 evokes the Eleusinian mysteries. Note also the amazing way (note the exclamation mirabile dictu, 2.30) that a living Olive root shoots out from the dry (dead?) wood (truditur e sicco radix oleagina ligno, 2.31)) in the Bacchic book 2.

${ }^{44}$ On allegory in book 4 of the Georgics, see further Morgan (1999).

${ }^{45}$ That is, those that purport to be intended to instruct. For the distinction between 'formally' and 'finally' didactic texts, see Heath (1985) 253. Formally didactic texts may not actually be intended to instruct, just as most commentators today do not believe that the Georgics was intended to be of practical use to farmers.
} 
addressees (Octavian, Maecenas, Romans in general), but if Aristaeus is Octavian, Octavian is clearly brought to the fore at this point, especially given his mention in the sphragis which immediately follows the episode (4.559-66). Octavian is given the prospect of apotheosis (1.24-42), but as Damien Nelis has recently stressed, ${ }^{46}$ this has not yet been achieved: it is still uncertain which council of the gods will claim him (quem mox quae sing habitura deorum/ concilia incertum est, 1.24-5), and there seems a real risk that Tartarus will choose him as their king (1.36-9). Octavian, then, has not yet achieved immortality. Whilst Virgil's poetry could hardly determine whether or not Octavian would be deified, it could prove instrumental in conferring a kind of poetic immortality. This seems to be encapsulated by the temple to Caesar that Virgil intends construct in book 3 (3.13ff.), which clearly functions as a metapoetic metaphor, perhaps referring to the Aeneid. ${ }^{47}$ The temple marks Octavian's divine status, given the number of sacrifices he will receive (3.22-3). In that case, his immortality, in a sense, depends upon Virgil's divinisation of him through song: to achieve this kind of poetic immortality, he must rely on Virgil just as initiates into Orphic mystery cult rely upon the songs of Orpheus to conquer death. Virgil is like Orpheus as his song will be instrumental in the divinisation of his addressee, Octavian.

Moreover, as in the case of the Orphic material, there is a crime that must be atoned for. In the Aristaeus narrative, this is the rape of Euridice; in the wider narrative of the poem, this seems to be the horrifying civil war described at the end of book 1 (461ff.), where right and wrong are inverted (quippe ubi fas versum atue nefas, 505). This was itself a punishment for an earlier crime, the perjury of Laomedon (satis iam pridem sanguine nostro/ Laomedonteae luimus periuria Troiae, 501-2). ${ }^{48}$ It may seem that this cycle of punishment is never-ending, but Virgil's exclamation that, for too long, Heaven has grudged Caesar's presence on earth (1.503-4) implies that Octavian may bring an end to it, just as the addressee of the Orphic tablets may bring an end to their lengthy cycle of reincarnations by purifying themselves of their ancestral fault. ${ }^{49}$ If we press the analogy with the Orphic model further, Octavian must achieve the 'purification' of the sins of Rome in order to attain divinisation.

The poem, then, presents the prospect of Octavian's divinisation, but that prospect is contingent upon his successful 'purification' of Rome from the crimes of civil war. To return to the Orpheus narrative, Octavian/Aristaeus has a choice whether or not to follow the instructions of Proteus, and, 'seeking peace' (petens pacem, 535), revitalize his hive of bees/ Roman citizens. In other words, he has a choice, whether or not to allow the complaints and lamentations of Orpheus/Virgil to have an effect on him. If he ignores them, Virgil's carmen, with its now empty praise of Octavian, will sound as hollow and haunting as the lamentations

\footnotetext{
${ }^{46}$ Nelis (2013) 253-4.

${ }^{47}$ See, e.g. Thomas (1988) ad loc.

${ }^{48}$ For further connections between the Bugonia episode and the end of book 1, see Morgan (1999) 200-2.

${ }^{49}$ Note especially OF 488.5 and OF 348.
} 
of Orpheus that have failed to persuade the manis and numina of the underworld (4.505), but remain to be heard long after his death (523-7).

\section{Bibliography}

References to Orphic Fragments marked 'OF' refer to the enumeration in Bernabé, A (20047). References to the fragments of Empedocles refer to their enumeration in Diels, $\mathrm{H}$. and Kranz, W. (1951-2).

Bernabé, A. (2002) 'La théogonie orphique du papyrus de Derveni' Kernos [Online], 15, Online since 03 September 2011, connection on 12 August 2014. URL: http://kernos.revues.org/1370

- - (2004-7) Poetae Epici Graeci Pars II Fasc. 1-3 Bibliotheca Teubneriana, MünchenLeipzig: K.G. Saur

Bernabé, A. and San Cristóbal, A.I.J. (2008) Instructions for the Netherworld Leiden-Boston: Brill

Betegh, G. (2004) The Derveni Papyrus: Cosmology, Theology and Interpretation Cambridge: CUP

- - (2014) 'Pythagoreans, Orphism and Greek Religion' in C.A. Huffman (ed.) A History of Pythagoreanism Cambridge: CUP pp.149-166

Bremmer, J. (2014) Initiation into the Mysteries of the Ancient World Berlin: de Gruyter

Burkert, W. (1969) 'Das Proömium des Parmenides und die Katabasis des Pythagoras' Phronesis 14 (reprinted in his Kleine Schriften VIII: Philosophica, Th.A. Szlezák, K.-H. Stanzel (edd.), Göttingen: Vandenhoeck \& Ruprecht, 2008 pp.1-27

- - (1982) 'Craft versus Sect: The Problem of Orphics and Pythagoreans', in B.F. Meyer, E.P. Sanders, (edd.), Jewish and Christian Self-Definition III: Self-Definition in the GraecoRoman World, London 1982, 1-22, 183-189 (reprinted in his Kleine Schriften III: Mystica Orphica, Pythagorica, F. Graf (ed.), Göttingen: Vandenhoeck \& Ruprecht, 2006 pp.191-216).

- - (2005) 'La teogonia originale di Orfeo secondo il Papiro di Derveni' in G. Guidorizzi, M. Melotti, (edd.), Orfeo e le sue metamorfosi. Mito, arte, poesia, Roma: Carocci 2005, pp. 46-64 (reprinted in German as 'Die altorphische Theogonie nach dem Papyrus von Derveni' in his Kleine Schriften III: Mystica Orphica, Pythagorica, F. Graf (ed.), Göttingen: Vandenhoeck \& Ruprecht, 2006 pp.95-111)

Clausen, W. (1994) Virgil: Eclogues Oxford: OUP 
Currie, B. (2007) 'Heroes and Holy men in Early Greece: Hesiod's Theios Aner' in Eroi, Eroismi, Eroizzazioni della Grecia antica a Padova e Venezia: Atti del Convegno Internazionale, Padova, 18-19 settembre 2006 (ed.) Alessandra Coppola, Padova: S.A.R.G.O.N. Editrice e Libreria , 163203

Diels, H. and Kranz, W. (1951-2) Die Fragmente der Vorsokratiker (6th edn. Berlin: Weidmann).

Dyck, A. R. (2003) Cicero, De Natura Deorum I Cambridge: CUP

Edmonds, R.G. (1999) 'Tearing Apart the Zagreus Myth: A Few Disparaging Remarks on Orphism and Original Sin,' Classical Antiquity 18.1 (1999), 35-73.

Edmonds, R.G. (2013) Redefining Ancient Orphism: A Study in Greek Religion, Cambridge: CUP Gale, M. (2000) Virgil on the Nature of Things Cambridge: CUP

Gowers, E. (2016) 'Under the Influence: Maecenas and Bacchus in Georgics 2' in P. Hardie (ed.) Augustan Poetry and the Irrational. Oxford: OUP

Graf, F. (1974) Eleusis und die Orphische Dichtung Athens in Vorhellenistischer Zeit, Berlin and New York: de Gruyter

- - (1985) Review of Martin L.West, The Orphic Poems, Oxford 1983, Gnomon 57, 585591.

- - (2006) "lacchus." Brill's New Pauly Antiquity volumes edited by: Hubert Cancik and, Helmuth Schneider. Brill Online, 2014. Reference. Oxford University libraries. 12 August 2014 http://referenceworks.brillonline.com/entries/brill-s-new-pauly/iacchus-e520740 First appeared online: 2006

Graf, F. and Johnston, S.I. (2007) Ritual Texts for the Afterlife: Orpheus and the Bacchic Gold Tablets. London and New York: Routledge

Hardie, A. (2002) 'The Georgics, the Mysteries and the Muses at Rome' PCPS 48 (2002) 175208

Hardie, P. (1985) Virgil's Aeneid: Cosmos and Imperium, Oxford: OUP

Heath, M. (1985) 'Hesiod’s Didactic Poetry' CQ 35: 245-263

Horsfall, N. (1993) ‘P. Bonon.4 and Virgil, Aen.6, yet again' ZPE 96, 17-18

Horsfall, N. (2013) Virgil, Aeneid 6, a commentary 2 Vols Berlin: de Gruyter

Hunter, R. (1993) The Agonautica of Apollonius: Literary Studies Cambridge: CUP

Janko, R. (2000) Philodemus: On Poems Book 1 Oxford: OUP 
Johnston, P. A. (1977) 'Eurydice and Proserpina in the Georgics' TAPhA 107: 161-172

- - - (2009) 'The Mystery Cults and Vergil's Georgics' in G. Casadio and P. A. Johnston (edd.) Mystic Cults in Magna Graecia. Austin: Univ. of Texas Press 251-273

Kingsley (1999) In the Dark Places of Wisdom Inverness, Calif.: Golden Sufi Center

Kouremenos, T., Parássoglou, G.M. and Tsantsanoglou, K. (2006) The Derveni Papyrus ed. with introduction and commentary (Studi e Testi per il Corpus dei Papiri Filosofici Greci e Latini, 13) Florence: Leo S. Olschki

Lightfoot, J. (2009) A Hellenistic Collection Cambridge, Mass.: Harvard Univ. Press

Luck, G. (1973) 'Virgil and the Mystery Religions' AJP 94 147-66

Mac Góráin, F. (2014) 'The Mixed Blessings of Bacchus in Virgil's Georgics' Dictynna 11 (http://dictynna.revues.org/1069)

Morgan, L. (1999) Patterns of Redemption in Virgil's Georgics, Cambridge: CUP

Mynors, R.A.B. (1990) Virgil: Georgics Oxford: OUP

Nelis, D. (1992) 'Demodocus and the song of Orpheus : (Ap. Rhod. Arg. I, 496-511). MH 49 153-170.

- - (2004) 'Georgics 2.458-542: Virgil, Aratus and Empedocles' Dictynna 1 (http://dictynna.revues.org/161)

- - (2013) 'Past, Present and Future in Virgil's Georgics', pp.244-262 in J. Farrell and D. Nelis (eds.) Augustan Poetry and the Roman Republic. Oxford: OUP

Norden, E. (1916) P. Vergilius Maro: Aeneis Buch VI (2nd edition), Leipzig: Teubner

Obbink, D. (1994) 'A Quotation of the Derveni Papyrus in Philodemus' On Piety' Cronache Ercolanesi 24 111-35

- - (1997) 'Cosmology as Initiation vs. the Critique of Orphic Mysteries' pp.39-54 in A. Laks and G. Most (eds.) Studies on the Derveni Papyrus Oxford: OUP

Parker, R. (1995) “Early Orphism," in A. Powell (ed.), The Greek World. London and New York: Routledge 483-510.

- - - (2011) On Greek Religion Ithaca and London: Cornell Univ. Press

Riedweg, C. (1995) 'Orphisches bei Empedokles' A\&A 41, 34-59

- - (2005) Pythagoras: His Life, Teaching, and Influence (trans. S. Rendall) Ithaca, NY: Cornell University Press 
Rodríguez, M.R. (2005) Orfeo y el orfismo en la poesía de Empédocles: influencias y paralelismos. Colección de Estudios, 98. Madrid: Ediciones de la Universidad Autónoma de Madrid (UAM Ediciones)

Thomas, R. (1988) Virgil: Georgics (2 Vols.) Cambridge: CUP

Trépanier, S. (2004) Empedocles: An Interpretation. London: Routledge

Ustinova, Y. (2009) Caves and the Early Greek Mind: Descending underground in the Search for Ultimate Truth Oxford: OUP

Vernant J.P. (1983 [1965]) 'Hesiod's Myth of the Races: An Essay in Structural Analysis' in his Myth and Thought among the Greeks London: Routledge (translation of French original Mythe et Pensée chez les Grecs, Paris) pp.25-52

West, M.L. (1983) The Orphic Poems Oxford: OUP 